\title{
住いとコンクリート
}

岡 島 達 雄

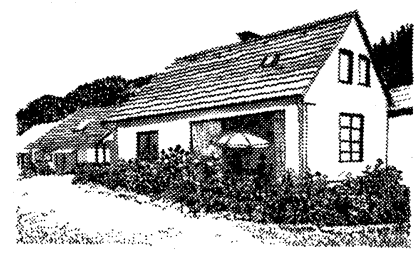

\section{1. 建物亡材料}

コンクリートは建物の材料です。人や物を支 え, 地震や風に抵抗する主たる構造材料である とともに, 壁や床の表面を構成寸る仕上げ材で もあります。建物に使われる材料は，れんがや 畳などいくらでもありますが，コンクリートは 最も多量に用いられ, 最も重要な材料の一つで す。そんな関係で, 眺めたり, 触れたり, 載っ たり，寄り掛かったりという，五官を通じての 人間とコンクリートの交流は緊密です。

その関係は，見たり，さわったりという，人 間からコンクリートへ㗢きかけてゆく場合と， 意識するしないにかかわらず，体熱を奪ったり 圧迫感や安心感を与えたりという, どちらかと いうとコンクリートが人間に働きかけてくる場 合の 2 通りがあります。いずれにしても, コン クリートが人間に及ぼす影響は，現代社会にお いて小さいものではありません。

ただここで考えなければならないのは，建 物の主要な材料がコンクリートではあっても， コンクリートはあくまで建物の一構成材料に過 ぎないことです。従って，人間がコンクリート に接するといっても，人間はコンクリートの建 物に相対するのであって, コンクリートに直接 相対するのではありません。建物は一つのまと まりであって，そのまとまりにこそ建物の建物 らしさがあると思うのです。

料理の栄養価は, その主たる材料によって支 配されますが，その味は主たる材料だけでは決 まりません。同じ材料を使っても，その焼きか げん，煮かげんや，ごくわずかの薬味によって うまくもまずくもなるのと似ています。

そういう意味で, 人間とコンクリートの関係
を，建物を介在させずに議論することは非常に 難しいことです。にもかかわらず，それにあえ て立ち问かわざるをえないのが本稿です。

\section{2. コンクリートのイメージ}

目を閉じて静かにコンクリートのことを思い 浮かべてみます。

白, 灰色, 硬くて冷たい, 荒々し

い，ガサガサ…...

等々の形容語句が出てきます。そして

味気ない, 殺風景な, 不快な, 退屈

な，危険な……

等々の価值観を表す語句がイメージされます。

表一 1 は, 昭和 53 年に 18 才から 26 才まで の男子大学生 5 名と女子大学生 8 名に, セメン 卜系材料 4 種を示して, その印象を簡単な形容 語句として書き記してもらったものを分類・整 理したものです。いずれも硬くて荒く，そして 冷たいというのが共通事項として取り出されま す。

そこで, 他の建築材料に比べて本当に硬・粗・ 冷なのかどうかを確認するための心理実験をや ってみました。使用しました材料は，金属，木 材, セメント, 石材, セラミックス, 石こう, プラスチックス, 繊維等の中から選んだ 33 種 類で, 方法は図式評定尺度法によりました。こ こでは，材料を直接目で見てさわった場合の粗 滑感, 硬軟感, 温冷感, 及び快・不快感につい

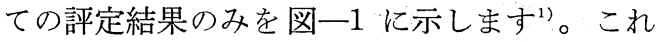
によると，七メント系材料は粗で硬で泠であ り，やや不快のところにきております。

もっとも，ここでセメントモルタル板といっ ても，数あるモルタル板の中のある特定の寸 法・形状・仕上げを持ったものの一例であって, 
表一1 セメント系材料の形容語句（カッコ内の数字は回数）

\begin{tabular}{|c|c|c|c|}
\hline 材 料 名 & 分 類 & さわって見る．見てさわる． & $2 \mathrm{~m}$ 離れたところから見る. \\
\hline \multirow{4}{*}{ 木毛セメント板 } & 粗 滑 & 荒々しい.ごわごわ.ざらざら. & $\begin{array}{l}\text { がさがさ (2). がたがた.ざらざらした. でこ } \\
\text { ぼこ.とて荒い. }\end{array}$ \\
\hline & 硬 軟 & & 硬い。 \\
\hline & 温 冷 & 冷たい. & \\
\hline & その他 & $\begin{array}{l}\text { うすぎたない.うす気味わるい(2). きたない. } \\
\text { くさっている.こわい.見ぐるしい. むやもや. }\end{array}$ & 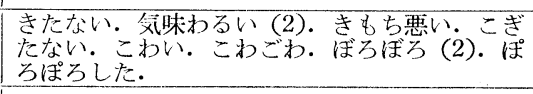 \\
\hline \multirow{4}{*}{ ALC } & 粗 滑 & ざらざら.するする. & かさかさ.さらさら. \\
\hline & 硬 軟 & & \begin{tabular}{|l} 
押寸とへこみそうな. 硬い. 柔らかそうな (2). \\
割れそう.
\end{tabular} \\
\hline & 温 冷 & & 冷たい (3). 冷やかな. \\
\hline & その他 & 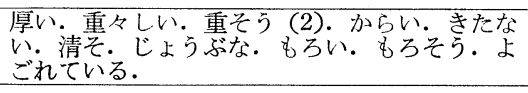 & 軽い. 流れるようだ. 安っぽい. \\
\hline \multirow{4}{*}{ 石綿スレート板 } & 粗 滑 & & こなこな.さららさら.すべすべ. ぱさぱさ. \\
\hline & 硬 軟 & & 硬そう。 \\
\hline & 温 泠 & 寒い.すずしい. & キリッとした冷たさ. 冷たい. \\
\hline & その他 & $\begin{array}{l}\text { 面白くない. 軽い.さみしそう．無表情な. 安 } \\
\text { っぽい. }\end{array}$ & 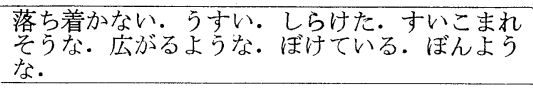 \\
\hline \multirow{4}{*}{$\begin{array}{l}セ x ン ン ~ \\
\text { モルタル 板 }\end{array}$} & 粗 滑 & $\begin{array}{l}\text { 荒い.ざらざら (2). ざらついている. ぶちちぶ } \\
\text { ち. }\end{array}$ & ごつごつした.ごろごろ. ざらざらした (6). \\
\hline & 硬 軟 & 硬い. & \\
\hline & 温 冷 & & 寒い. 寒けのする. 冷たい. \\
\hline & その他 & $\begin{array}{l}\text { 愛想がない. 重い.きたない. 暗い. ぼりぼり. } \\
\text { もろい. }\end{array}$ & 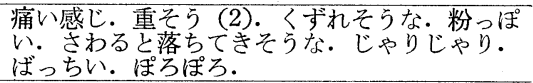 \\
\hline
\end{tabular}

モルタル板を代表するようなものではありませ h。

確かに, とがって硬いものは危険であり, 不 快であります。さわって冷たいものは，われわ れの身体から熱を奪い，快適なものではありま せん。表一1 のその他のところで, 污い, 気味 がわるい, しらける，落ち着かない等々，不快 な形容語句の出てくるゆえんです。残念なが ら,これが, コンクリートからわれわれが受け る一般的な印象であり,イメージでありましょ 5 。

コンクリートは, 白く, 荒々しく, 重く, そ して冷たい。反人間的であります。しかし，だ からこそ, 人間と自然の間, 人間と社会の間に 立って，よく人間を守ることができるのではな
いでしょうか。力に強く，火に抵抗し，音をよ く遮り, 腐ることもありません。わが国には珍 しく，すべての原料を国内でまかなえます。コ ンクリートは信頼されています。信頼されて多 くの重要な建築物に用いられています。それゆ えにこそ, 美しく, 優しくもあってほしいと望 まれるのではないでしょうか。武骨ではあるが 頼もしい,とのコンクリートの一般のイメージ を打ち消さないよう努力しようではありません か。

\section{3. 足の冷えとコンクリート}

部屋の温度，床の温度が同じでも，床材料に よって足の泠え方が違うことは, 体験的に知ら れています。鈴村博士らは, 年令 $20 \sim 23$ 才の 
3 名の健康な女性を使って 2 年間にわたる実験 を行い，次のような結論を出されました ${ }^{2)} 。$

床材をコンクリート, ビニール・タイル及び なら材とした模型室内で, 通常の服装をし, 靴 を履いた被験者に 1 時間読書をさせます。その 間の足の甲，ふくらはぎ及びひざの皮膚温度を 熱電対で測定して抒ります。季節は春及び秋
で, 室温, 床温ともに $18 \sim 22^{\circ} \mathrm{C}$ の間で一定の 場合の膝の温度変化を記録したのが図一2 す。この図で, 1 時間の読書作業前後の温度差 だけみると多少コンクリートが大きい程度です が, 室温 $18 \sim 22^{\circ} \mathrm{C}$ の範囲内での 1 時間経過後 の温度幅は, 木材床で狭く, コンクリート床で 大きくなっています。さらに，いずれの条件で
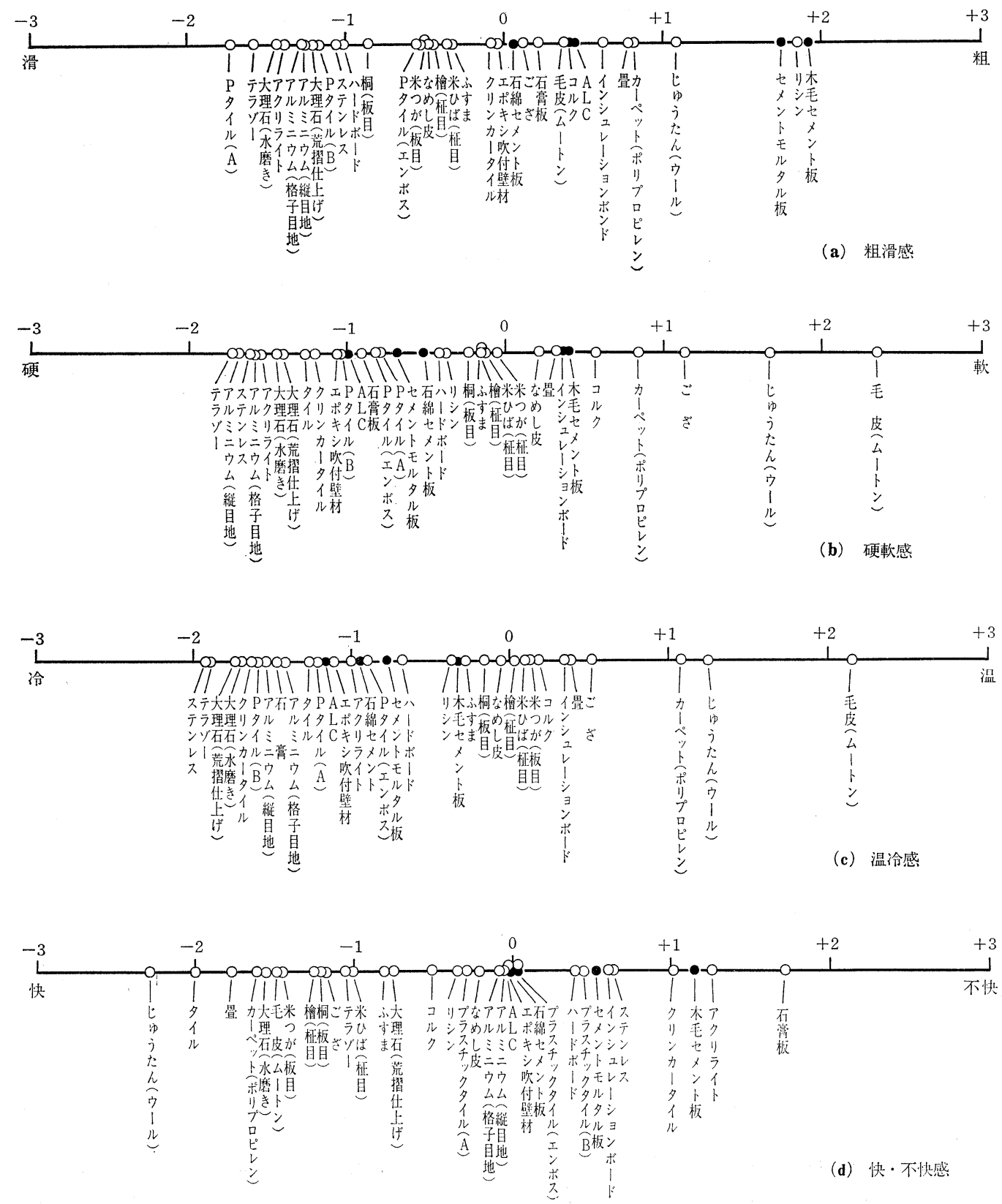

図一-1建築材料の感覚度（・印はセメント系材料） 

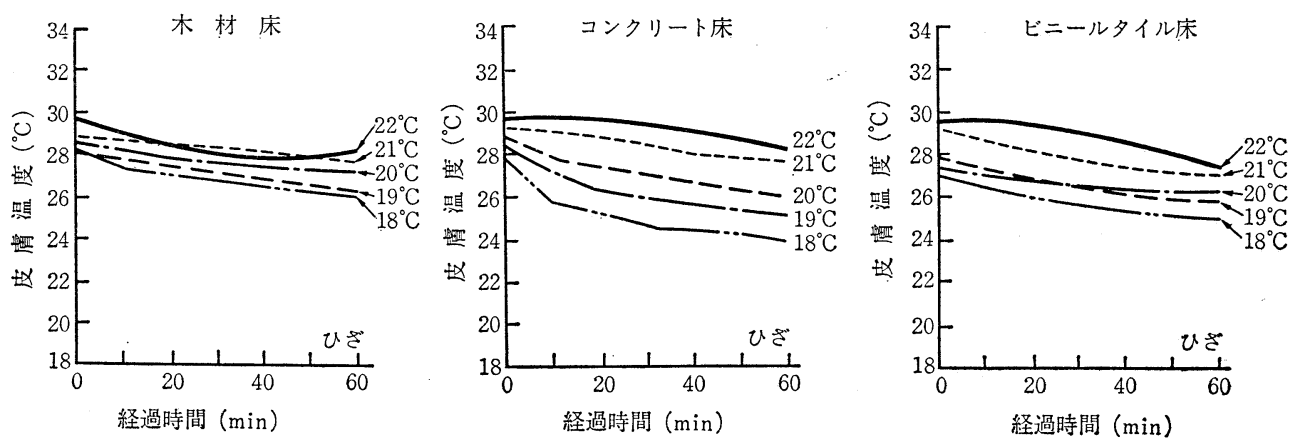

図一2 床材料の違いによる皮膚温度の時間的変化 ${ }^{2)}$

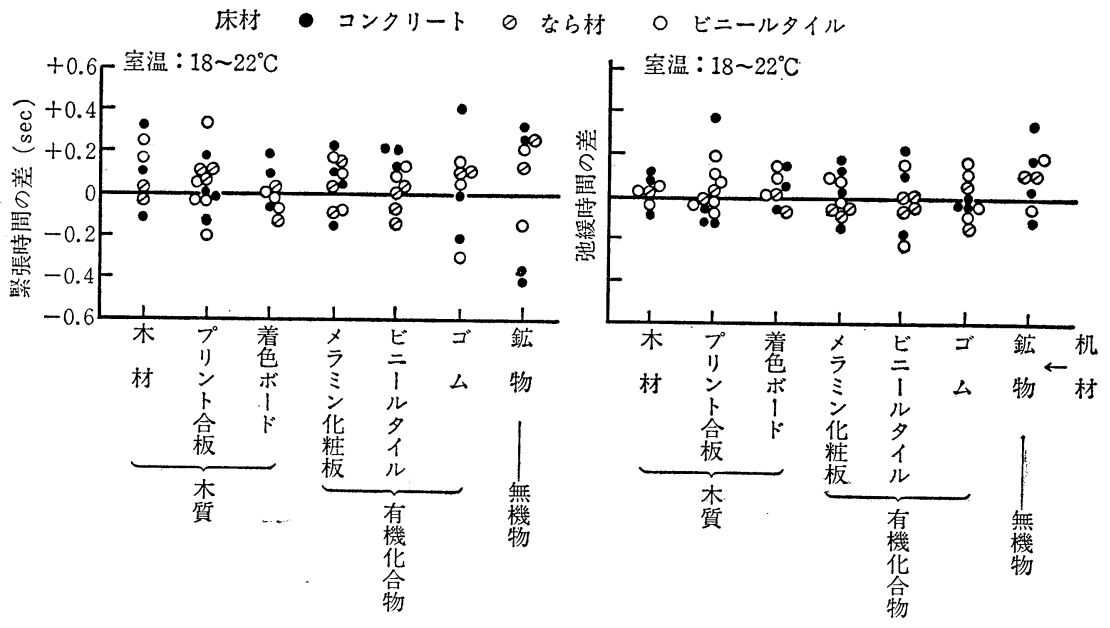

図一3 材質の相違による調節時間の変動 23

もコンクリート床が早く冷えています。この ような傾向は, 足の他の部位や別の季節におい ても共通しています。室温の変化にともなう皮 膚温度と室温の差は, 室温が同じならば空気温 度と体温との関係だけで決まりそうですが, 実 験の結果は床材料によって大きく変わることを 示しています。

鈴村博士らは，この実験に加え，机の天板の 仕上げ材料を 7 種類に変化させ, H.S. 自記眼 精疲労計による調節時間の実験前後の変動か ら, 眼調節機能の変化を測定しておられます。 図一3 にその測定例を示しますが，調節時間 は，机の材料によるよりは，むしろ床の材料に より大きく影響を受け, コンクリート床の場合 に一番激しく,木造床の場合に最も安定してい るという結果です。

本稿でご紹介できなかった実験結果も含める と, 足寒及び眼精疲労のこのような傾向は, 冷
房時に特に顕著になるようでして，長い間には 何か悪い影響を与えることも十分考えられる， と結んでいます。

限られた実験結果でもありますし，床仕上げ 材料が同じでも，下地を含んだ床構法によって も，その結果が大きく変わる可能性もありまし ようが，われわれの体験や想像からも十分うな ずける結果だけに留意すべきことでありましょ う。

\section{4. 理想の材料}

アレグザンダー教授の『建築定石集』尚の中か ら材料に関するものを拾い出し，私なりに要約 したのが次のものです。

「望ましい建築材料とは，重機などがなくて も持ち運びができる程度の大きさで, 現場で簡 単に切断でき, 形を整えるのが容易なもの，生 産に多くのエネルギーを要さず，生物などによ 
って風化するもので, かつ比較的安価なもので ある (207)。

外壁材料は, 寸法の小さい部材を積み重ねて 何段階かで雨風・寒暑を防ぐ方式が良い。損傷 した時には，その部位だけを取り替えられるも のが良い(234)。

内壁材料は, さわった時に硬すぎたり, 冷た すぎたりしてはならない。さもないと内装が難 しくなったり，音が響いてしまう。だから，す べての内壁を,さわって温かく，軟らかにする。 そうして, 小さな釷や鋲が打てるようにし，押 すと，いくらかはへこむようでなければならな い。洨喰は非常に良い。織物, 藤製品などもこ の条件を満足する。余裕があるなら，木材はな お結構だ (235)。

床材料は 2 手に分ける。公的空間用と私的空 間用だ。前者は, テラゾー, れんが, タイル， また硬木などの硬い材料を使用する。時には外 部の舗装材料と同じものでもよい。私的空間用 としては, より温かく, より軟らかい材料とす る。フェルトや鶕などを下地とし，その上を布 や織物で覆うとよい(233)」

さらに教授は続けます。

「普通のコンクリートは, 硬くて冷たい。容 易に切ったり削ったりすることができない。鋲 や釷を打ち込むことも難しい。壞れても素人に よる補修は困難だ。それに, コンクリートの肌 は醜く, その感触も良くない」

として, 比重 $0.5 \sim 1$, 強度 $40 \sim 70 \mathrm{kgf} / \mathrm{cm}^{2}$ ぐ らいの軽量コンクリートを主体材料に提案して います。確かに現在の普通コンクリートは硬く て強く, 構造材料には適していても, 仕上げ材 料, 特に内装材料としては硬すぎます。押すと へこむか, 少なくともへこむような感じのする くらいの硬さであってほしいものです。ぶつか ると傷つくのは, いっも人間側というのでは困 るのです。

構造材としては, 強いことが何よりなのでし ょうが, もう少ししなやかであってほしいと思 います。そして引張りや曲げに対しても, 今の 2 3 倍くらいの抵抗力のあるものが作れない ものでしょうか。セメント化学者やコンクリー ト材料学者の奮起を望むものです。
比重 0.5 1 のコンクリートというと, ALC や気泡コンクリートがそれにあたります。いず れも構造材料ですが, どちらかというと, 準構 造材料としての役割しか果たしておりません。 その理由は, 通常のコンクリート構造物の断面 寸法にほぼ等しく, 軽量コンクリートのそれを 決めようとする傾向があるからです。空間の有 効利用ということもあるでしょうが, 低強度で あれば, それなりの大きな断面寸法を与えてや れば, 純構造材料として十分使用できるものと 思います。厚い壁，それをくり抜いた開口部な ど,スペースさえあれば，良い建築の要素とな る可能性大といえましょう。強いコンクリー ト，壊れにくいコンクリートの研究開発ばかり でなく，弱いコンクリート，しなやかなコンク リートを使用する構法学, 構造学も, デザイン の開発とともにやってみる必要があるように思 います。

\section{5. コンクリート魂}

木の魂のことを末魂 (木霊) と呼ぶことがあ ります。木の育つ様や朽ち果てる様, また切ら れて材木となり, 建物や家具となって私達の生 活の一部になるのをみる時, たしかに木は生き 物だ，と心から感じることがあります。われわ れと同じように現に生命を宿していたり，かつ て生命を持っていたという親近感, 害を与えな いという意味での安心感等々，そこにわれわれ は，木の魂をみるのです。

石についても，似たような感情を抱くことが あります。

石には，かつては生体を構成していたものも ありますが，大部分はそうでないにもかかわら ず，木と同じょうに感じることのあるのはなぜ でしょうか。おそらく，石も木と同じように， その組織や構造には方向性や不均一性があっ て，木目に代わる石目というょうなものを持 ち, その石の素性や履歴を表すものが刻まれて いるからではないでしょうか。いずれも，われ われが刻んだものではなく，神の意志により刻 まれたものと思われる特有の組織や構造を持っ ています。

建築材料の中で, 木と同じ有機物のプラスチ 
ックスや，石と同じ無機物のコンクリートにも 魂を見い出したり, また逆に魂を植え付けるこ とのできる人もいるかも知れませんが，極めて まれでありましょう。これは，コンクリートや プラスチックスが天然・自然に存在するもので なく，人間の造った人工物であるからかも知れ ません。しかし，同じプラスチックスでも，布 や人エレザーとして衣服やかばん等に使われる ものは，その風合いが天然のものと変わらず, さらにその他の性質は天然のそれをはるかにし のぐものも多くあるようです。このようなもの の組織や構造は, 一般に細かく, その繊維のよ じれや絡みが天然のそれに近いと言われており ます。ロールスロイス・オブ・ファブリックと 呼ばれる人工スエード (鹿皮) が出回り, コー ト, スーツ, 帽子等に多量に使われるようにな りました。これは天然スエードをお手本にし て, その組織・構造を他の材料で構成したもの で, 天然で淂られない, 水洗いのきく長大な 布が得られる上に, その風合いは天然のそれと 変わりません。むしろ欠点は, 天然のスエード のようなむらのないことかも知れません。図一 4 に示したものは, 左側がこの人エスエード, 右側が天然スエード，そして上側が表面，下側 が内部です。両者の組織・構造に類似性が認め られませんか。

木材に木目という独特の組織・構造のあるこ とは，すでに述べたとおりです。その結果，繊 維方向とそうでない方向とで強度や収縮に差が

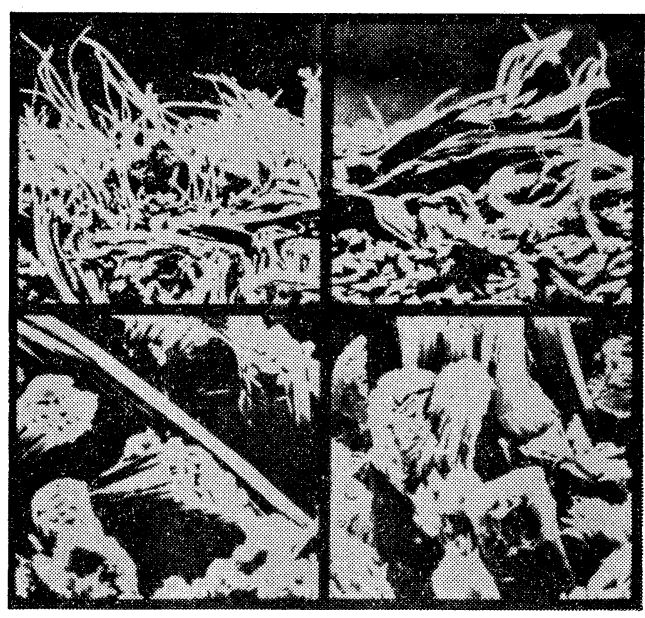

図-4人エスエードと天然スエードの顕微鏡写真4)
生ずる異方性という性質があります。ところが 合板は, 単板を交互に 90 度違えて重ね合わせ, 木材の欠点をなくしたといいますが，それだけ 木材の特長をも殺すことになっています。例え ば, 普通の柱やはりのように, 主として材軸方 向の応力を受ける部材には, 天然の木材のよう に異方性材料の方が効率が良いのです。

単板を同一方向にはり合わせて大断面とした ものに, 単層積層材 LVL (Laminated Veneer Lumber）という木質材料があります。抜け節 等の集中した木材の欠点を分散し, 異方性とい う木材の特長を最大限に生かし, かつ木材の風 合いを残したものです。

色調や硬さの異なる湾曲したプラスチックス の単板を何枚か積層接着し，硬化したところで スライスすると, 単板の曲面に応じた模様が表 面に表れます。何年も使っているうちに，表面 の模様に沿って軟らかい部分が摩滅し, 硬い部 分だけがくっきりと浮かび上がるということに なります。長期間使用しなくても，サンドブラ ストなどの表面処理を施すことによって似たよ うなものを作り出すこともできましょう。その 模様はプリント合板のような表面だけの化粧で はなく，その組織・構造が表出したものですか ら，損傷などした時に化けの皮がはがれるとい う心配がありません。またその模様は，木材に 似たものでもよいし，似て否なるものでもよい でしょう。天然の木材と材質も異なり，パター ンも異なる木質的な非木質材料が得られるかも 知れません。

木材には，環境湿度が高くなると吸湿し，低 くなると放湿するという，いわゆる調湿作用が ありますが，そのメカニズムを究明し，その機 構を他の材質の組織・構造に置き換えることに より，非木質材料でも，木質的な吸放湿特性を 備えた材料が出てくる可能性があります。

種類や産地の異なる粘土を粗くこね混ぜ, 成 形して焼き上げ，その色調や微妙な肌ざわりの 違いの効果を䄈らった練り込みと称する作陶法 があると聞きます。

コンクリートに魂を吹き込むにも，これくら いのことは考えなりればならないでしょう。 


\section{6. 美しい風化}

外気にさらされたコンクリートは, 雨, 風, ガス, 塵埃等によって時代とともに変質してゆ きます。この変化により建物が醜くなるか, 逆 に風格を増し趣きを添えるかは, 設計者のコン クリートに対する理解と建物の将来に対する洞 察, 施工者の入念な工事, それから使用者の建 物に対する愛情と管理にかかわっています。

構造材には，使いなれて十分自信のもてる材 料しか使わない，とか，30 年後の姿を見てほし い, と語られた村野藤吾氏の世界平和記念聖堂 をみてみましょう。聖堂は, 昭和 20 年 8 月 6 日広島に投下された原爆の犠牲者への追憶と慰 霊のためと, 全人類の友愛と平和のしるしとし て建立されたものです。昭和 25 年 8 月 6 日定 礎， 4 年後の昭和 29 年同月同日献堂。構造体, 内·外装, 空枠, 彫刻等, ほとんどがセメント・ コンクリートで作られています。多くの人々の 熱意と愛情で作られたと言われていますが，設 計・施工の入念さには頭の下がる思いがします。 約 30 年を経過しようとする建物ですが，コン クリート特有の白けた灰色はなく, 粗面に仕上 げた壁面には苔がはっています。コンクリート はアルカリ性のため, 通常は植物は生育しにく く, 草が生えるほどに中性化の進んだコンクリ
ートは耐力もなくなっているはずです。 御堂外壁のへこみに，いちはやくほこりが取 り付き, 雨水を吸い, やがて風とともにやって きた植物が住みついたのでしょうか。壁面に比 べるとやや滑面の柱・はりは打放し仕上げです がここにもうっすらと苔生しています。この 色は打設直後のコンクリートの色に近いのです が，自然のかもし出す斑のもたらす効果が建物 に梁みを与え,さらに銅板ぶき屋根と, そこか ら落ちる水径とに美しく映えています。空や彫 刻にも，色やテスクチャーの異なるモルタルや コンクリートが多数用いられていますが, 素材 がどれもセメントであるという点で，この建物 の性格を象徴しています。

コンクリートの機能的な良さを殺さずにコン クリートの悪いイメージをぬぐい，さらに 30 年がかりでコンクリートの美しさを引き出して います。質素で親しみやすい建物ではあります が，わたしたちをぬかづかせずにおかない空間 構成の大役を, コンクリートが担っています。 設計者の豊かな感性に基づく御堂空間には, 石 造建築の技法と木質の伝統空間の構成法が脈々 と流れているょうに感じるのは筆者だけでしょ うか。

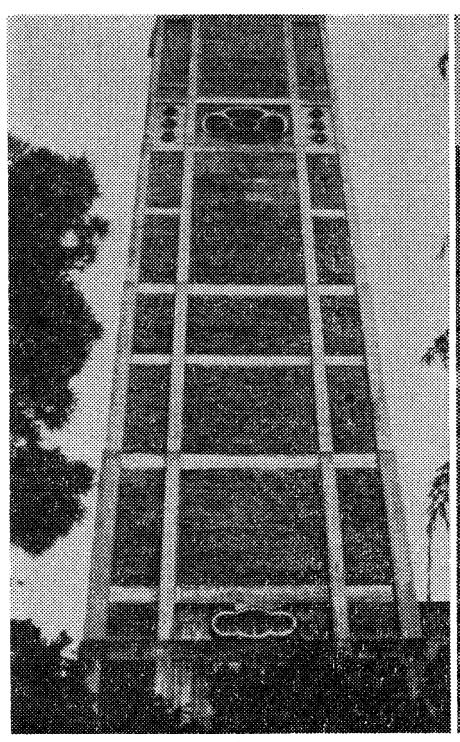

(a)

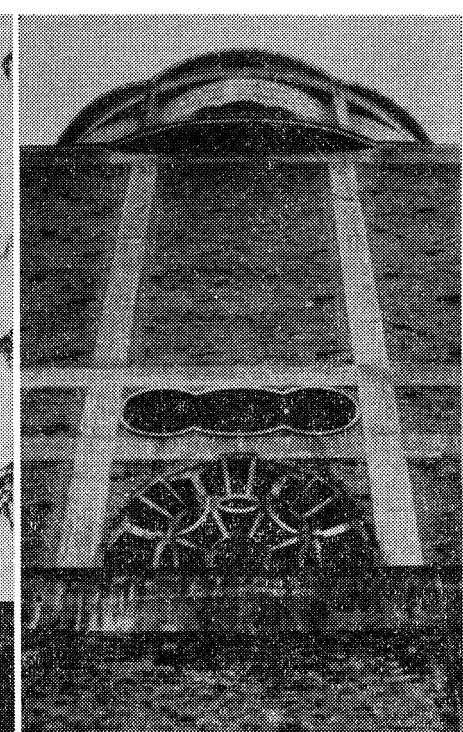

(b)

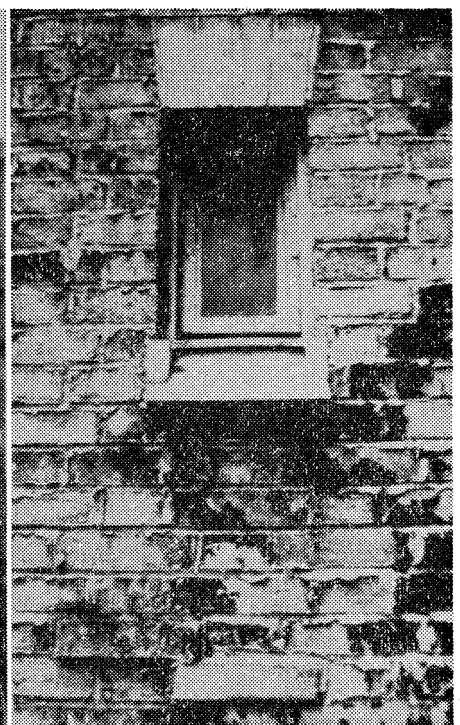

(c)

図一5 世界平和記念聖堂 


\section{7. 再び建物と材料}

建物の良し悪しは, 材料自体よりも, その材 料の用い方によって決まってきます。選択でき る材料の数や構法の種類は, 時代の経過ととも に多くなり，デザインの自由度は増えてきます が，それだけに一個一個の材料に対する経験に 裏打ちされた理解度は, 一般的に年々薄くなっ ていくのではないでしょうか。そこには技術だ けでなく, 豊かな感性が要求されます。鉄とガ ラスとコンクリートで構成される近代建築の創 始者が, 材料の本質を究めるために, 石工やガ ラス職人として，それぞれ数年間の修業をした ことを知る時，おのずからわれわれのなすべき ことが分かってくるのではないでしょうか。

謝 辞 材料と足の泠え, 材料と眼精疲労の関係 についてご教示下さいました, 愛知医科大学 鈴村 昭弘教授に厚く御礼申し上げます。

1）岡島達雄ほか：建築仕上げ材料の感覚的評価に関する 研究, 建築学会論文報告集, 309 号, 1981.11, pp. $1 \sim 10$.

2）鈴村昭弘ほ力：生活環境と眼精疲労，臨床眼科，20 巻, 4 号, 1966.4.

3) A. Alexander, et al. : A Pattern Language, Oxford University Press, 1977.

4）カタログくエクセーヌ >, 東レ (株).

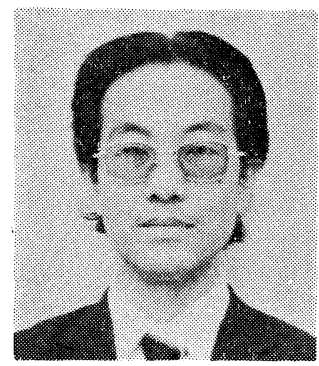

\section{おかじま たつお}

1940 年, 徳島県生れ。東 京工業大学卒業。工学博士。 名古屋工業大学講師を経て, 現在。同大学助教授 (建築学 科)。コンクリートの力学的 挙動, 建築仕上げ材料の感覚 的評価に関する研究を行う。 著書「建築材料学入門」。 